\title{
Teaching speaking
}

\author{
Heini-Marja Pakula, University of Turku
}

\begin{abstract}
To be able to communicate fluently in a foreign language is the number one goal for many language learners. However, it seems that the teaching of oral skills in language classrooms does not have an important role. There are many reasons: the higher status of written language, teaching to the tests (of written language), teaching the textbook (with emphasis on written language), and lack of knowledge of how to teach speaking. The purpose of the article is to discuss the issue of how foreign language (FL) speaking can be taught based on 1) how speaking is learned and 2) how speaking proficiency is defined. More specifically, 1) How do learning theories translate into teaching speaking at classroom level? and 2) What is the significance of the current understanding of language proficiency as reflected in the models of communicative competence and the Common European Framework (Council of Europe, 2001) and its Companion Volume with New Descriptors (Council of Europe, 2018) to the teaching of speaking in formal foreign language contexts? On the basis of the theoretical and research reviews, some pedagogical implications and suggestions for research are provided. The pedagogical implications concern the teaching of fluency and formulaic sequences, the teaching of spoken grammar, the teaching of linguistic, sociolinguistic and pragmatic competences. Classroom applications of the sociocultural theory include pair and group work, communicative activities with opportunities for the negotiation of meaning, and creative spoken production. It is suggested that teachers' pedagogical content knowledge (PCK) be applied as a means to integrate theory with classroom applications. Suggestions for related research are provided.
\end{abstract}

Keywords: foreign language learning, foreign language teaching, teaching oral skills, language teacher education

\section{Introduction}

Speaking is an important skill in language learning, but it is not an easy skill to learn or teach. There are a number of reasons why oral skills are not taught in language classrooms. If oral production is not included in tests, teachers might not want to use precious class time for oral production but instead teach to the test and prioritize grammar, written or reading skills. Another (related) reason may be that the teaching methods and materials emphasize written language and grammatical correctness as learning goals. Even if the approach is "advertised" as communicative (Communicative Language Teaching, CLT), it may be that oral language is rarely used in the classroom, or even if there are interaction activities and simulations, it may be that the type of oral production does not promote

Corresponding author's email: hemajar@utu.fi

ISSN: 1457-9863

Publisher: Centre for Applied Language Studies

University of Jyväskylä

(C) 2019: The authors

http:/ /apples.jyu.fi 
learning as defined as a psycholinguistic or sociocultural process (Corbett, 2003). It is also possible that the teacher feels uncertain about her/his spoken language proficiency and avoids speaking the target language in class and provides few opportunities for the students to speak in class. The same applies to students, who may be afraid of making mistakes and being criticized.

As research into teachers' pedagogical content knowledge (PCK, see Shulman, 1986, 1987) about teaching oral skills is scanty (Borg, 2006; Chen \& Goh, 2014), it can be speculated that due to the emphasis on teaching (and testing) written language and grammar, teachers may not feel confident in their ability to teach speaking, that is, their PCK about learning and teaching speaking is insufficient. One of the objectives of the present article is to contribute to the teachers' PCK about teaching speaking by providing them with a combination of "content and pedagogy" (Shulman, 1987, p. 8), which would act as a bridge between theory and practical implementation. "An understanding of how particular topics, problems, or issues are organized, represented, and adapted to the diverse interests and abilities of learners, and presented for instruction" (Shulman, 1987, p. 8) constitutes the core of teachers PCK about learning and teaching speaking in their contexts.

The blend of content and pedagogy that is offered in the present article consists of a theoretically informed account of speaking and some applications that have been shown successful in teaching oral skills in classroom contexts. The two frameworks that the discussion draws on are learning theories and the notion of speaking proficiency (communicative competence). In other words, the purpose of the article is to discuss the What and How of teaching speaking. The question What should we teach when we teach speaking? refers to the speaking competences that are part of an individual's language proficiency, or communicative competence, as defined in the Common European Framework (Council of Europe, 2001) and its recent update, the Companion Volume (Council of Europe, 2018). Some answers to the question How should we teach speaking? are searched for in the two major theoretical strands, the psycholinguistic and sociocultural theories, and related research. It should be noted that the discussion does not attempt to be a comprehensive account of teaching speaking but rather a discussion of selected issues, which will lead to a fruitful interaction of theory and practice for the teacher-researchers who are teaching speaking in their ecological context.

The structure of the remaining article is as follows. Section 2 begins with a discussion of speaking in the framework of the two major strands of language learning theories, the cognitivist-psycholinguistic and the sociocultural theories. In each section, the first part is an introduction to the theory and the latter part provides implications for teaching speaking.

\section{How are oral skills learned? Speaking and learning theories}

There are two major language learning theories, the more traditional cognitive psycholinguistic theories and the more recent sociocultural theories. The psycholinguistic view emphasizes the individual's internal cognitive and psycholinguistic processes in language learning, whereas the sociocultural view gives priority to social interaction in learning. Due to their different ontological origins, these two views are often viewed as conflicting, incompatible and parallel (Zuengler \& Miller, 2006). In her influential article, Sfard (1998) uses two metaphors to describe two different views of learning. The acquisition metaphor 
refers to learning as accumulating and storing information (the psycholinguistic tradition). The participation metaphor involves the idea actively taking part, becoming part of something bigger (the sociocultural view). One might want to point out that the acquisition metaphor may have been an apt metaphor in a grammar-translation classroom, but it is an obsolete one in modern communicative foreign language classrooms, where language use is prioritized. Thus, communicative foreign language teaching is not based on the idea of solely acquiring language knowledge (lexis and rules) but it aims at using language for meaningful communication, which is a characteristic of the participation metaphor (Sfard, 1998, p. 7). The present discussion is focused on the pedagogical applications of the two theoretical strands, the psycholinguistic and the sociocultural to the teaching of foreign language speaking.

Below, both views are discussed from the viewpoint of oral language production. The psycholinguistic view (2.1) begins with a discussion of proceduralization (or automatization), a key component in achieving fluency, which is discussed next followed by the teaching of fluency. Another key component in achieving fluency is formulaic language. The section ends with a discussion of formulaic language and its teaching. Section 2.2 discusses the potential of the sociocultural theory in teaching speaking in the foreign language classroom. Practical applications of the two central components of the Vygotskyan theory, two-planeness and the Zone of Proximal Development, are discussed in teaching speaking.

\subsection{The psycholinguistic theories}

Teaching foreign language oral skills in the classroom has traditionally been informed by the cognitive psycholinguistic tradition with a focus on individual learning processes (Long \& Doughty, 2003; Skehan, 1998). Psycholinguistic processes, such as implicit and explicit learning, declarative and procedural knowledge, proceduralization and automatization, are related to fluent language production. Implicit learning is an automated process and not available for conscious inspection. Implicit processes are primarily in charge of L1 learning, but they are also involved in L2 learning together with explicit processes, which are available for conscious inspection. Declarative knowledge refers to the 'what' of learning: explicit knowledge, vocabulary knowledge and knowledge of rules (grammar). Procedural knowledge refers to the actual language use that is enacted in language production and reception. Fluent speaking is learnt as a result of proceduralization. Proceduralization takes place when learners draw on declarative knowledge by picking a declarative morphosyntactic rule, using it in communication a number of times, and by the repeated use of the same rule, they gradually form procedural knowledge, establishing a habit after some repetition, then gradually automatizing this habit, and perhaps eventually forming implicit knowledge. The end products are not always full automatization and implicit knowledge for all rules and for all language learners, but proceduralization is a necessary prerequisite for fluent language use (DeKeyser, 2017; Hulstijn, 2002, 2011). This view represents an interface position which allows a facilitative relationship between declarative and procedural knowledge. A non-interface position denies all contact between the two types of knowledge, claiming that declarative knowledge cannot turn into procedural knowledge, and only implicit knowledge can be proceduralized (Paradis, 2004, 2009). According to Paradis (2009, p.8), formal teaching can speed up the explicit, metalinguistic knowledge, 
not proceduralize it. Nevertheless, speeding up of spoken production may be a satisfactory goal for most language learners and teachers alike. But what is fluency and how can it be taught? These issues are discussed below.

\subsubsection{Fluency}

Everyday definitions of fluency are often based on listeners' impressions of smooth and effortless, native-like speech, but the numerous definitions of fluency that have appeared in research literature (Chambers, 1997; Ellis, 2009; Koponen \& Riggenbach, 2000; Lennon, 1990) imply that it is a complex and multi-faceted, fluid concept. Fluency has been analyzed quantitatively (Lennon, 1990) as speech temporal phenomenon (Schmidt, 1992) with a focus on automatization, speech rate and length of pauses, but also qualitatively as increasing length of linguistic units (mean length of runs (MLR), Towell, Hawkins \& Bazergui, 1996). More recently, fluency is perhaps seen as a dynamic notion comprising the underlying cognitive mechanisms and the social environment (Segalowitz, 2016). This type of cognitive fluency (Segalowitz, 2010) with proceduralization may be related to indepth learning and overall development of proficiency.

\subsubsection{Teaching fluency}

There is ample research on the nature of fluency, but research on how to teach fluent speaking is scanty (Derwing, 2017, p. 253). It is, however, possible to find tasks that have been shown to promote fluency development in research, some of which are discussed below.

Task repetition has been shown to increase oral fluency (Bygate, 2001; Bygate \& Samuda, 2005). The assumption is that by repeating the (same) task, proceduralization takes place and frees up attentional resources which are then available to the speaker for selection of words, morphemes and syntactic structures. De Jong and Perfetti (2011) used timed task repetition in which students recorded the same speech three times, using first 4 minutes, then 3 and finally 2 minutes (Nation, 1989). It was found that the number of words and the extent of vocabulary increased for each repetition. They argued that proceduralization of linguistic knowledge effected a change in the underlying cognitive mechanisms. This change was observable as increased fluency. Lambert, Kormos and Minn (2017) found that immediate aural-oral same task repetition led to improved fluency regardless of proficiency level. Tracking is an imitation technique where learners repeat or read out loud an aural passage at the same time as they hear it. The process is repeated multiple times. In shadowing, learners' repetition "lags a bit behind" the original passage (Rossiter, Derwing, Manimtim, \& Thomson, 2010, p. 597). The purpose of the above activities is to prompt repetition, which is necessary for proceduralization and automatization. It may be that teachers tend to avoid any repetition, practice and drilling due to the bad reputation of the audiolingual method, which was based on endless and often meaningless repetition, assumed to lead to stimulus-reaction chains and habit formation. It often led to superficial learning, not to transfer of learning to creative production. However, psycholinguistic research has shown that repetition is necessary for automation: "lexical information simply must be reactivated regularly for it to remain quickly accessible" (Hulstijn, 2001, p. 286).

Based on research results, Wood (2001, pp. 583-586) suggests a teaching program to teach fluency. The program starts with an awareness raising phase 
(Input) where learners listen several times to a recording (a native speaker involved in an informal discussion), first discussing the content and clarifying comprehension and finally paying attention to hesitations and formulaic sequences ("chunks" of words discussed below). In the automatization phase, the learners are involved in a shadowing activity, imitating the transcribed speech a number of times until they feel they are in control of the speed, pauses and lexis, formulaic sequences in particular. Next, the learners do two activities, the dictogloss and a mingle jigsaw. In the dictogloss activity (Wajnryb, 1990), a text (rich in formulaic sequences, from the input phase) is read aloud twice. The learners work in groups and reconstruct the text in collaboration. The dictogloss was developed for developing grammar awareness, but according to Wood (2001, p. 584), it has great potential for developing automaticity and fluency. In the mingle jigsaw, the learners have been assigned a number of formulaic phrases from the input text on paper. Having memorized them, they mingle and share their phrases or sentences (no notes) with peers and receive theirs. They then write down all the formulaic language that they have come across. The mingle jigsaw is based on repetition to promote automatization and further fluency. These activities are followed by a chat circle to consolidate the experience gained. In the next stage (practice and production stage), the learners prepare a 4 -minute talk, deliver it to their partners first in four, then three and finally in two minutes. The purpose of the $4 / 3 / 2$ activity (Nation, 1989) is to enhance fluency (faster pace, less hesitations) by delivering the same content in reduced time. The final activity is free creative production. According to Wood (2001), the type of "pedagogy of fluency" built upon the type of tested activities described above integrates the components of automatization (result of practice and repetition), creative construction and formulaic competence and may be used in the classrooms.

\subsubsection{Formulaic language}

Another important component of fluent language use is formulaic language, which consists of language stored in pre-fabricated formulas, such as collocations (bread and butter); phrasal verbs (run into); idioms (a piece of cake); and figures of speech (as cold as ice); as well as lexical bundles, which include

a) polywords that serve functions such as qualifying (e.g., as far as I know), disagreeing (e.g., no way), and shifting topics (e.g., that reminds me);

b) institutionalized expressions such as proverbs (e.g., the early bird gets the worm) and social formulae (e.g., long time no see, nice to meet you);

c) phrasal constraints that permit a range of variation (e.g., a day/year/long time ago; good morning/afternoon/evening); and

d) sentence stems (e.g., I suggest that . . ; Why don't you . . .?) (Nattinger \& DeCarrico, 1992).

Formulaic sequences are chunks of two or more units (e.g. words) stored and retrieved as a single unit from memory (Wray, 2002). Prefabricated language is chunked, that is, "compressed" to formulas which use less working memory (WM) capacity than non-formulaic language and consequently leave room for higher level processes, such as planning the next move in conversation (Dörnyei, 2009, pp. 294-297; Ellis, 2003). 
Knowledge of formulaic sequences has been shown to be a sign of general L2 proficiency (Boers \& Lindstroemberg, 2012), and the users of formulaic sequences have been assessed as proficient speakers in their L2 (Boers, Eyckmans, Kappel, Stengers, \& Demecheleer, 2006). According to Wray (2002, pp. 186-187), formulaic sequences are important language elements in the first stages of learning until novel sequences are being produced. They occur occasionally ("patchy presence") in intermediate and advanced learners" language, but they resume "full presence by the time a learner achieves native or near-native competence" (Wray, 2002, p. 187).

However, it has also been shown that L2 learners find learning formulaic language challenging, as they lack native proficiency in using formulas (e.g., Howarth, 1998; Pawley \& Syder, 1983). It is possible that learning formulaic expressions is difficult due to differences in the processing of formulas between L1 and L2. It may be that L2 learners have problems noticing formulaic expressions, but it may also be that L2 learners do not feel empowered or see the point in harvesting L2 input in larger chunks to become effective communicators (Wray, 2002, p. 236).

\subsubsection{Teaching formulaic language}

First language formulas have been acquired implicitly and unconsciously, and first language speakers are not consciously aware of them. In L2 learning, formulaic sequences need to be noticed in spoken and written texts. To identify formulaic chunks in stretches of language, learners need to know what they are looking for. For example, Nattinger and DeCarrico's (1992) classification of formulaic sequences may be used to teach learners to notice, learn and use formulaic language.

The first step in teaching formulaic language is consciousness-raising about the occurrence of multiword expressions in texts. Example 1 below is a text chosen from a French textbook for beginners (CEFR A1-level) Escalier 1 (Granath, Laine, \& Penttilä, 2018, pp. 108-109) to exemplify some multiword expressions that learners of French as a second foreign language may encounter.

Example 1. Thérèse et Émile ont faim ['Thérèse et Émile are hungry']

Thérèse et Émile sont en ville pour faire du shopping. Maintenant, ils sont fatigues. Ils ont faim et ils ont soif. ['Thérèse and Émile are in town for shopping. Now they are tired. They are hungry and thirsty.']

\begin{tabular}{|c|c|}
\hline Thérèse & J'ai faim. On mange? ['I'm hungry. Shall we eat?'] \\
\hline Émile & Oui, bien sûr. Moi, j'ai soif aussi. ['Yes, sure. I'm hungry, too.') \\
\hline Thérèse & $\begin{array}{l}\text { On va au MacDo pour prendre un hamburger? ['Shall we go to MacDonald's } \\
\text { for a hamburger ?'] }\end{array}$ \\
\hline Émile & Je n'aime pas trop le fast-food. ['I don't really like fast food.'] \\
\hline Thérèse & On va où alors? ['Where shall we go then ?'] \\
\hline \multirow[t]{2}{*}{ Émile } & $\begin{array}{l}\text { On va au restaurant " La Marmite ». ['Let's go to the restaurant «La } \\
\text { Marmite». '] }\end{array}$ \\
\hline & Ils ont des salades super bonnes ! [’They have great salads !'] \\
\hline \multirow[t]{2}{*}{ Thérèse } & Tu ne manges jamais de viande ? ['You don't eat meat, do you ?'] \\
\hline & $\begin{array}{l}\text { Moi, je ne veux pas de salade... Mais, d'accord, on y va. ['I don't want a } \\
\text { salad... But okay, let's go.'] (Granath et al., 2018, p. 108) }\end{array}$ \\
\hline
\end{tabular}


Following Nattinger and DeCarrico's (1992) teaching sequence, in the consciousraising phase, the students would focus on the formulaic expressions in the text by underlining them first without the recording, then with the help of listening to the recording of the text. They would then compare and discuss their choices in class. To identify formulaic sequences, it is important to listen to the group accent, which refers to the group of words separated by rhythmic group boundaries. A prosodic unit is indicated by (optional) initial stress, but more importantly by stressing the last syllable in a prosodic unit that marks the end of the unit (Horgues, 2013, p. 43). It is useful to provide the learners with declarative knowledge about the specifics FL spoken formulas, as the knowledge of such features is helpful in both identifying and producing fluent spoken language. In Example 1, a beginner learner of French as a foreign language is likely to identify frequently occurring multiword chunks, such as on y va, d'accord and bien sûr. In addition to fixed idioms, they may spot some productive structures, such as on va (au MacDo / on va où alors / on va au restaurant «La Marmite »).

In the next step, the formulaic sequences are reproduced, first in gapped texts (scaffolded activity), then in free production (enabling the language user to transfer the learned language to new contexts and internalizing it). An example of a reproduction activity (Rossiter et al. 2010, pp. 589-590) is disappearing text: The teacher gradually deletes an increasing number of formulaic sequences which the learners replace. Phrases are deleted until all the words are gone, and the learners are repeating the passage and the formulaic sequences from memory. Disappearing text might be applied to Example 1 above, perhaps after practicing selected expressions and structures, for example different continuations to on va.

In the last step, free production, the learners use (some of) the formulas in their own contexts. Beginner learners may need support (scaffolding) in the production phase, for example it may be useful to leave the frame of the dialogue and instruct the learners to modify the dialogue by adding to it their own preferences (pizzeria, oriental, gourmet, fish, meat, vegetables). It is important to offer opportunities to meaningful production even for beginners. The internalization of formulas requires formulaic language be used in a variety of contexts as part of creative language construction.

So far, the emphasis of the article has been on achieving fluent production by means of ample repetition. It needs to be stressed that the goal of teaching speaking is free meaningful production and that automatization and fluency activities are only a means to achieving this goal. It is important to avoid mechanical repetition, boredom and to prevent the repetitive activity from leading to superficial learning, which was one of the cons of the audio-lingual method deriving from the behaviorist notion of learning.

The psycholinguistic approach is concerned with what happens within the individual while $\mathrm{s} /$ he is learning to speak a foreign language to be able to use it in interaction with others. We will next turn to the sociocultural approach and look at a different view of language learning.

\subsection{Sociocultural theory in teaching speaking}

According to the sociocultural theory (SCT), language learning is a social process (Block, 2003; Lantolf, 2000). Language is constructed in interaction with others; it is gradually internalized and ultimately becomes the property of the individual. The modern application of SCT draws on Vygotsky's notions of two-planeness of 
learning and the Zone of Proximal Development (ZPD). Two-planeness of learning refers to learning taking place first in contextual interactions and then on an individual level where higher order cognitive capacities are developed. The ZPD refers to the developmental space which is formed between a novice (e.g., a beginning language learner) and an expert (e.g., a teacher, more advanced peer). These novice-expert interactions are mediated by tools, which may be physical (e.g., computers) or symbolic (e.g., gestures, language). Higher-order capacities can be developed through collaborative problem-solving activities. The concrete and specialized other-directed activity is extended through internalization and it becomes the property of the individual to be used independently in similar (but not identical) functions (Lantolf, 2007, p. 696; Lantolf \& Thorne, 2006, p. 79).

Applications of sociocultural theory in language classrooms are most often based on Vygotsky's notion of two-planeness and Zone of Proximal Development. According to Schinke-Llano (1993), the progression through the ZPD involves three stages: The learners "move from object-regulation (a stage in which the facts of the environment control the learner) to other-regulation (in which an 'expert' mediates by providing strategies) and finally to self-regulation (in which the learner controls the activity)" (Schinke-Llano, 1993, p. 22). This sequence has been applied to language teaching and to research (e.g., Aljaafreh \& Lantolf, 1994; Machado de Almeida Mattos, 2000; Ohta, 1995).

Brooks and Donato (1994) analyzed the collaboration of L1 English students studying L2 Spanish in their third year focusing on the features of semiotic mediation, a Vygotskyan concept, which refers to the irreducible unit that the individual learner, language, actions, task and the goal of the mediational activity form. Brooks and Donato (1994) analyzed students' use of speaking as object regulation (how learners make sense of and control the task itself), as shared intention (how the learners negotiate and form a joint perspective about how to carry out the task the task), and as goal formation (how the learners express their individual and joint goals or plans during interaction). In all the above steps, the learners are involved in metatalk, negotiating the task requirements (object regulation), orientating themselves (shared orientation) in relation to the task, and externalizing the goal of the activity (goal formation). The learners are not following the manuscript of a communicative activity, for example, but they are involved in an idiosyncratic metacognitive activity (Brooks \& Donato, 1994).

To beginning language learners, participating in semiotic mediation is challenging (if not impossible) due to the restricted linguistic resources in the target language. However, in conveying individual meanings, the learners are allowed to use their L1 or other languages as metatalk. The use of L1 as a scaffold is likely to help beginning language learners to progress in language internalization.

One problem with the use of the Vygotskian framework in research is to show that internalization has taken place. In Machado de Almeida Mattos's (2000, p. 340) research, internalization was signaled by the participant's use of a word that he had learned from another participant during previous interaction. It is questionable if a one-time occurrence can be a sign of permanent learning, but the contribution of one participant regulating others (and vice versa) is a sign of the importance of collaboration in mediational activity. Dao and Iwashita's (2018, p. 191) remark concerns the issue: "it should be pointed out that whether the learners in this study [Dao and Iwashita's study] would retain and use these items autonomously later (i.e., internalize new psychological tools to execute new 
psychological functions) is not known since no measure was delivered to test this development".

In the same vein, it is difficult to assess the mediation having taken place in Niu, Lu and You's (2018) research, which focused on four proficient Chinese English FL learners' oral language experiences. Interviews and written journal data revealed that there were in all 13 sociocultural resources (artifacts, rules, community, roles) that mediated the participants' oral English learning. A number of the mentioned artifacts were conventional study materials, such as textbooks and other learning materials. Being advanced and skillful learners, the four studied EFL students may have followed their accustomed study habits in using the available materials.

The potential of the socioculturally oriented language teaching may best serve intermediate and advanced level students with developed metacognitive and metalinguistic skills. In van Compernolle and Williams' (2012) application of the SCT, the focus is on collaborative interactions and instructional conversations, which rely on the linguistic component and require developed metalinguistic skills.

\section{Speaking and communicative competence}

During the last forty, fifty years, the notion of language proficiency has shifted from focus on language as a linguistic system towards language as a means of communication. At the same time, the teaching of languages has moved from teaching language as a grammatical system to teaching language as communication (communicative language teaching, CLT). Pedagogical developments were made possible by theoretical insights in the 1980s, when Canale and Swain's model of communicative competence was presented (Canale, 1983; Canale \& Swain, 1980. In addition to the linguistic component, grammatical competence, the model contained sociolinguistic and strategic (=compensatory) competences. In more recent models of communicative competence (Bachman, 1990), strategic competence has an important role as an executive, metacognitive or metalinguistic component in message creation, monitoring and repair. The most recent model of communicative competence is The Common European Framework of Reference for Languages: Learning, Teaching and Assessment (Council of Europe, 2001), which was recently complemented by an update with new descriptors: The Common European Framework of Reference for Languages: learning, teaching, assessment. Companion volume with new descriptors. (Council of Europe, 2018)

In the Common European Framework of Reference (Council of Europe, 2001), communicative language competence consists of linguistic, sociolinguistic and pragmatic competences. Linguistic competence comprises the language user's knowledge and skills of language as a system, sociolinguistic competence refers to its variations, comprising "rules of politeness, norms governing relations between generations, sexes, classes and social groups, linguistic codification of certain fundamental rituals in the functioning of a community" (Council of Europe, 2001, p. 13), and communication between participants from different cultures. Pragmatic competence refers to "the functional use of linguistic resources (production of language functions, speech acts), drawing on scenarios or scripts of interactional exchanges. It also concerns the mastery of discourse, 
cohesion and coherence, the identification of text types and forms, irony, and parody" (Council of Europe, 2001, p. 13).

The Common European Framework has adopted an action-oriented approach to language use, in which language learners as 'social agents' carry out tasks defined as "actions performed by one or more individuals strategically using their own specific competences to achieve a given result." (Council of Europe, 2001, p. 9 ). This approach to language learning, teaching and assessment is a general one (Council of Europe, 2001, p. 9) and so is the approach to language teaching methodology, which "has to be comprehensive, presenting all options in an explicit and transparent way and avoiding advocacy or dogmatism." (Council of Europe, 2001, p. 142).

The present discussion focuses on how speaking proficiency is defined in the Common European Framework (Council of Europe, 2001) and its Companion Volume (Council of Europe, 2018) and how speaking can be taught in the foreign language classrooms to enable learners to become competent speakers of the language/s studied. The discussion does not attempt to be comprehensive, but instead it purports to illustrate and suggest instructional approaches and pedagogical applications that have been shown to promote the learning of spoken skills.

The remaining section is structured as follows. Oral linguistic competence is dealt with in section 3.1 in the form of spoken grammar. Sections 3.2 and 3.3 focus on sociolinguistic and pragmatic competences respectively.

\subsection{Teaching communicative language competences}

The purpose of this section is to illustrate some ways of teaching speaking from the viewpoint of communicative language competences, linguistic, sociolinguistic and pragmatic competence. Pragmatic contexts define the appropriate sociolinguistic language to be used. Linguistic competence provides the language resources for speaking.

\subsubsection{Linguistic competence: spoken grammar}

Compared to written grammars, spoken grammars are a relative newcomer in the field of language teaching. For the production of spoken language, a knowledge base of the relevant features of spoken grammar needs to be taught and learned. According to Carter and McCarthy (2017, p. 6), one should teach features of spoken grammar that (a) are markedly more frequent or differently distributed in speaking, (b) have been neglected or overlooked because of the emphasis on writing as the source of grammatical description (e.g. aspects of speech reporting and the notion of subordination), and (c) further illuminate face-to-face speaking and the conditions under which it unfolds (e.g. ellipsis and the headers and tails). (Carter \& McCarthy, 2017, p. 6). Some such features are exemplified below (Hilliard, 2014, pp. 2-14):

\begin{tabular}{|c|c|}
\hline Ellipsis & Any questions? (Do you have any questions?) \\
\hline Heads & $\begin{array}{l}\text { The soccer game last night, it was really exciting (The soccer game last night } \\
\text { was really exciting) }\end{array}$ \\
\hline Tails & $\begin{array}{l}\text { My teacher is really nice, the one from America. (My teacher from America is } \\
\text { really nice) }\end{array}$ \\
\hline Fillers & er, well, hmm, um \\
\hline Backchannels & uh-uh, oh, yeah, I see \\
\hline
\end{tabular}


In addition to the above features, spoken language displays syntactic differences, such as more verb-based phrases instead of nominalizations, more predicative adjectives instead of head-initial adjectives, more pronouns, especially firstperson reference, less impersonal passive constructions, and more use of coordination (and, but). One notable feature of speaking is the frequency of chunks or prefabricated utterances, especially in conversations, that make up more than 50 per cent of a spoken text (Erman \& Warren, 2000).

\subsubsection{Teaching spoken grammar}

There seems to have been little progress on the question of how we should teach spoken grammar (Timmis, 2005, p. 117). McCarthy and Carter (1995, pp. 216-217) propose an I-I-I paradigm (Illustration-Interaction-Induction), which they do not claim to be a specific methodology. The first I (Illustration) refers to the presentation of the material with the objective of raising awareness of target features and developing students' noticing, Interaction refers to using the language, and Induction to the conclusions that the learners draw about the task.

One problem with teaching features of spoken grammar is the lack of such features from teaching materials, both texts and activities. Spoken dialogues are plentiful in beginner textbooks, but the most frequent features of spoken grammar are personal reference and occasionally ellipsis. Heads, tails, fillers and backchannels are non-existent. They may exist in recordings of spoken language, but if they do, they are not practiced in activities.

Example 2 is an example of how one can work with existing textbook dialogues to better illustrate features of spoken grammar. Students were instructed to add fillers and backchannels to the text. In Example 2, fillers and backchannels are added in italics.

Example 2. Working with a textbook dialogue (Hilliard, 2014, p. 10)

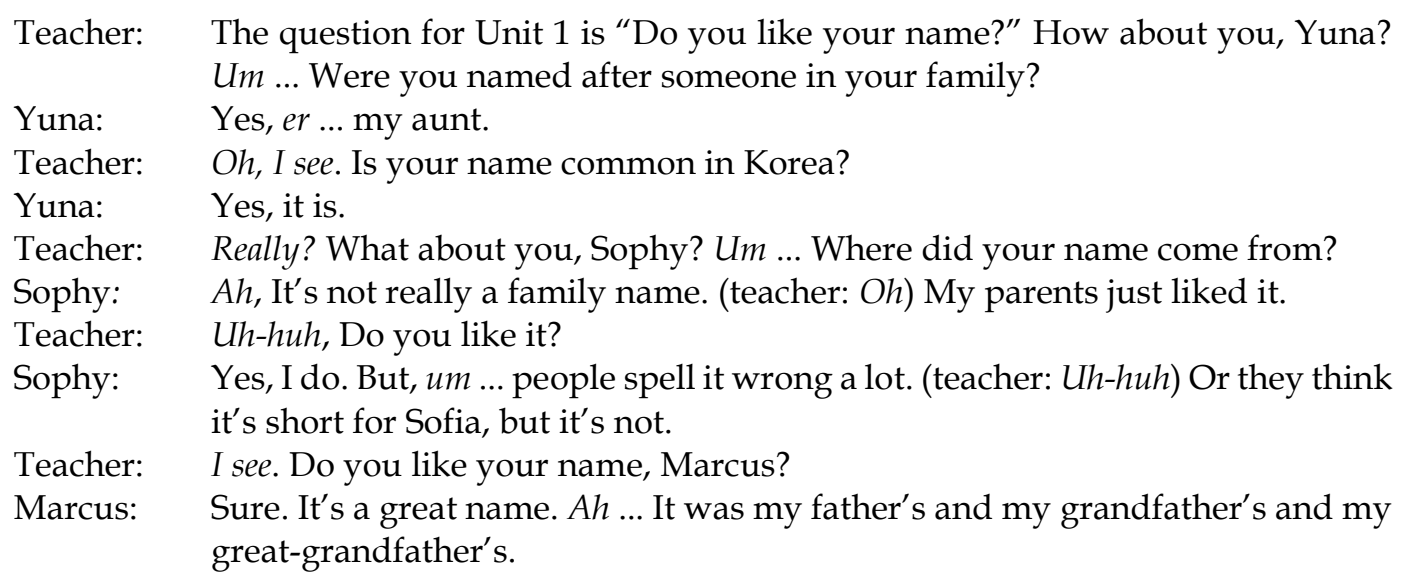

\subsubsection{Teaching sociolinguistic competence}

Sociolinguistic competence refers to the appropriate use of language in social situations: to know and be able to use linguistic markers of social relations, politeness conventions, register differences, dialect and accent. In the Common European Framework (Council of Europe, 2018), there is one scale for sociolinguistic appropriateness. Its key concepts include the following: 
- using polite forms and showing awareness of politeness conventions;

- performing language functions in an appropriate way (at lower levels in a neutral register);

- socialising, following basic routines at lower levels, without requiring the interlocutor(s) to behave differently (from B2) and employing idiomatic expressions, allusive usage and humour (at $\mathrm{C}$ levels);

- recognising sociocultural cues, especially those pointing to differences, and acting accordingly; adopting an appropriate register (from B2). (Council of Europe, 2018, p. 136)

In the teaching of sociolinguistic conventions that differ from one language and culture to another, one might want to start with observing the conventions in the target language and compare them with corresponding L1 sociolinguistic conventions. The differences are not always obvious which is why instructional discussions are useful.

Politeness is also culture-specific. What is polite in one culture may be an insult in another. There are different degrees of politeness and a good start to learn politeness is to sensitize oneself to different expressions of politeness. For example, one might start rating the degree of politeness in different expressions: Shut up! / Please be quiet! / Be quiet! or Ta gueule! / Silence. / Tais-toi, s'il te plaît.

More demanding activities involve situations with complications where one has to weigh the degree of politeness carefully, such as asking a friend to pay back the money that they had borrowed a couple of weeks back but not paid back as promised (Kim, 1994). To be able to navigate successfully in such situations, learners need to have a fairly advanced language competence, ample experience from different sociolinguistic devices and situations.

\subsubsection{Teaching pragmatic competence}

Pragmatic knowledge refers to the way language is used to communicate in a variety of different contexts. Doing things with words in context, for example to suggest something, advise somebody, to offer or request, is realized as speech acts (Austin, 1975; Searle, 1969). For second and foreign language learners, who are not familiar with the sociocultural contexts and conventions of the target language, speech acts of requests, apologies, refusals and compliments may be challenging to learn. Obviously, the appropriate use of speech acts is best learned in authentic communication, but there are pedagogical approaches with the purpose of teaching speech acts in the FL classroom. Although the results are controversial, it seems that explicit teaching has an effect on the pragmatic (and sociolinguistic) competence, even more significant than a study abroad context (see, e.g. Taguchi, 2011).

To be able to communicate in various speech situations, one needs to have a repertoire of various "gambits", such as speech acts and turn-taking devices. In many cases, such devices are pre-fabricated and context-specific. Speech acts and adjacency pairs, devices are exemplified below.

Fujimori and Houck (2004, pp. 2-8) suggest a three-step programme for teaching speech acts. The first step aims at consciousness-raising of speech acts and their functions. Some examples might be eliciting functions for speech acts, such as This is really nice, this wine! (praise, evaluation) and Why don't you sit down! (suggestion, not a question). The focus of the next phase is knowledge building. The students' task is to identify advice-giving forms: 
Example 3. Speech acts: Consciousness-raising

Are the following sentences direct, softened, or indirect?

1. You should see The Lord of the Rings.

2. Maybe, you might enjoy seeing The Lord of the Rings.

3. The new The Lord of the Rings is great. I really enjoyed it.

In the next step (Production development, spoken responses), learners produce appropriate speech acts in different, sometimes delicate situations:

Example 4. Speech acts: production (role-play)

Read the role play card that you have been handed (A or B). Think about what you would say. Then perform the role-play with your partner.
Card A: You and a friend are going to eat at a restaurant. Your friend says she/he will order the tempura special. You've eaten there before, and the tempura wasn't very good. You think she/he should order something else.

Card B: You and a friend are going to eat in a restaurant. You love to eat tempura, so you're going to order the "tempura special."

For beginning language learners, a simplified scheme may be offered. The teacher might scaffold the activity by giving the instructions in L1 and some target language vocabulary, such as appropriate gambits (What would you ...? I'd like.../I love.../I'm allergic to...)

Speech acts are often paired utterances where the second member of the pair is dependent on the preceding one, for example questions and answers. Disjunctive and display questions are often answered either yes or no or in one word, which is not conducive for language use and learning. To build up a reservoir of adjacency pairs, a variety of speech acts may be taught and practiced in a number of different situations, perhaps in role-plays and preferably at a more advanced stage. Beginners may start with learning frequently occurring prefabricated speech acts, such as greetings (Hello! - Hi!, Ça va? - Ça va bien!, Ciao, Valeria! - Ciao, Marcello!), functional questions and answers (Ça fait combien un T-shirt? - Ça fait 18 euros. Quanto costa questa camicia?-100€.)

Everyday conversations are often interactions with the function of maintaining social relationships. Small talk or phatic communication is often routinized communication between strangers. It has beginnings and ends and turns that are relatively fixed. Starters may deal with "safe" topics, such as the weather (parler de la pluie et du beau temps):

Il fait beau! Beautiful day, isn't it? Com'è il tempo? - C'è bel tempo. Everyday conversations are very common in spoken language. Their function is to maintain the social channel and keep up social relations. Everyday conversations have a relatively fixed structure: they start with greetings, then some "niceties" (I love your dress!) or comments about some safe topic, such as the weather may be exchanged. Then the speakers start preparing to end the conversation (OK, I've got to dash now! Oops, it's late, I'll miss my bus.) and finish off by taking leave (See you soon/Talk to you soon/Bye-bye.)

\section{Concluding remarks}

The purpose of this article is twofold: to inform the teaching of foreign language speaking in the foreign language classroom firstly by providing a theoretical basis 
for classroom implementations and secondly by suggesting avenues of research to explore the teaching and learning of speaking in the foreign language classrooms. To achieve these goals, an overview of the psycholinguistic and sociocultural theories was provided as well as a discussion of speaking as a component of language proficiency as reflected in the Common European Framework and its Companion. Based on the discussion of the three sources, a number of recommendations and suggestions may be given regarding teaching and research:

- Fluency can be taught by using carefully designed fluency-oriented activities (consciousness-raising and rehearsal/repetition activities)

- Formulaic sequences are part of fluent speech and they can be taught.

- Spoken language is a "language" in its own right and it should be taught (and tested, see Figueras in this volume) as such.

- Teaching speaking includes teaching and practicing sociolinguistic competence (formality, politeness conventions)

- Teaching speaking includes teaching and practicing pragmatic competence (conversation, turn-taking, speech acts)

- Teaching speaking involves the teaching of the three modes of speaking: interactional and transactional speech and spoken mediation.

We need research on

- the impact of fluency-oriented activities on promoting fluency (and learning) in the foreign language classrooms.

- the "teachable" features of spoken grammar in the target languages (other than English).

- the teaching and learning of sociolinguistic and pragmatic competence in the foreign language classrooms.

- the teaching and learning of spoken interaction and transaction and, in particular, on spoken mediation in the foreign language classrooms.

- the potential of the sociocultural approach in the teaching of speaking to beginner learners

- the implementations of the sociocultural theory in formal language teaching context.

More research is also needed about language teachers' PCK about teaching speaking, in particular about how PCK about speaking is construed and implemented in the classrooms. Because pedagogical content knowledge (PCK) includes teachers' understanding of how students learn specific subject matter, the development of PCK is an important goal to focus on in professional development programs. Recent re-conceptualizations of teachers' PCK highlight its complex and contextual nature (Hashweh, 2005; Santiago Sanchez \& Borg, 2014; Van Driel \& Berry, 2012)

This implies that the development of teachers' PCK should be closely aligned to teachers' professional practice and, in addition to providing teachers with specific input, should include opportunities to enact certain instructional strategies and to reflect, individually and collectively, on their experiences.

There are obvious implications to language teacher education, both preservice and in-service. In addition to providing teachers with up-to-date information about learning, teaching and assessing speaking and thus adding to and updating their PCK, it is important to deal with beliefs about teaching speaking that may hinder teachers from fully committing themselves to the teaching of speaking (Raman, 2017) and focus on enhancing teachers' self-efficacy beliefs as proficient teachers of oral skills. 


\section{References}

Aljaafreh, A., \& Lantolf, J. P. (1994). Negative feedback as regulation and second language learning in the zone of proximal development. The Modern Language Journal, 78(4), 465-483.

Austin J. L. (1975). How to do things with words. Oxford: Oxford University Press.

Bachman, L. (1990). Fundamental considerations in language testing. Oxford: Oxford University Press.

Block, D. (2003). The social turn in second language acquisition. Edinburgh: Edinburgh University Press.

Boers, F., Eyckmans, J., Kappel, J., Stengers, H., \& Demecheleer, M. (2006). Formulaic sequences and perceived oral proficiency: Putting a Lexical Approach to the test. Language Teaching Research, 10(3), 245-261.

Boers, F., \& Lindstroemberg, S. (2012). Experimental and intervention studies on formulaic sequences in a second language. Annual Review of Applied Linguistics, 32, 83-110.

Borg, S. (2006). Teacher cognition and language education: research and practice. London: Continuum.

Brooks, F. B., \& Donato, R. (1994). Vygotskyan approaches to understanding foreign language learner discourse during communicative tasks. Hispania, 77(2), 262-274.

Bygate, M. (2001). Effects of task repetition on the structure and control of language. In M. Bygate \& M. Swain (Eds.), Researching pedagogic tasks: second language learning and testing (pp. 23-48). London: Longman.

Bygate, M., \& Samuda, V. (2005). Integrative planning through the use of task repetition. In R. Ellis (Ed.), Planning and Task Performance in a Second Language (pp. 37-74). Amsterdam: John Benjamins.

Canale, M. (1983). From communicative competence to communicative language pedagogy. In J. C. Richards \& R. W. Schmidt (Eds.), Language and Communication (pp. 2-27). London: Longman.

Canale, M., \& Swain, M. (1980). Theoretical bases of communicative approaches to second language teaching and testing. Applied Linguistics, 1(1), 1-47.

Carter, R., \& McCarthy, M. (2017). Spoken grammar: Where are we and where are we going? Applied Linguistics, 38(1), 1-20.

Chambers, F. (1997). What do we mean by fluency? System, 25(4), 535-544.

Chen, Z., \& Goh, C. (2014). Teacher knowledge about oral English instruction and teacher profiles: an EFL perspective. Teacher Development, 18(1), 81-99.

Corbett, J. (2003). An intercultural approach to English Language Teaching. Clevedon, UK: Multilingual Matters.

Council of Europe. (2001). Common European framework of reference for languages: Learning, teaching, assessment. Cambridge: Cambridge University Press.

Council of Europe. (2018). Common European Framework of Reference for Languages: Learning, teaching, assesment. Companion volume with new descriptors. Retrieved from http://rm.coe.int/cefr-companion-volume-with-new-descriptors-2018/1680787989

Dao, P., \& Iwashita N. (2018). Teacher mediation in L2 classroom task-based interaction. System, 74, 183-193.

De Jong, N., \& Perfetti, C. A. (2011). Fluency training in the ESL classroom: An experimental study of fluency development and proceduralization. Language Learning, 61(2), 533-568.

DeKeyser, R. (2017). Knowledge and skill in ISLA. In S. Loewen \& M. Sato (Eds.), Routledge handbook of instructed second language acquisition (pp. 15-32). New York: Taylor \& Francis.

Derwing, T. M. (2017). L2 Fluency development. In S. Loewen \& M. Sato (Eds.), The Routledge handbook of instructed second language acquisition (pp. 246-259). New York: Taylor \& Francis.

Dörnyei, Z. (2009). The psychology of second language acquisition. Oxford: Oxford University Press.

Ellis, N. C. (2003). Constructions, chunking, and connectionism: the emergence of second language structure. In C. J. Doughty \& M. H. Long (Eds.), The handbook of second language acquisition (pp. 63-103). Oxford: Blackwell. 
Ellis, R. (2009). The differential effects of three types of task planning on the fluency, complexity, and accuracy in L2 oral production. Applied Linguistics, 30(4), 474-509.

Erman, B., \& Warren, B. (2000). The idiom principle and the open choice principle. Text, 20(1), 29-62.

Fujimori, J., \& Houck, N. (2004). Practical criteria for teaching speech acts. The Language Teacher, 28(5), 3-8.

Granath, M., Laine, K., \& Penttilä, R. (2018). Escalier 1. Helsinki: Sanoma Pro Oy.

Hashweh, M. Z. (2005). Teacher pedagogical constructions: a reconfiguration of pedagogical content knowledge. Teachers and Teaching: Theory and Practice, 11(3), 273-292.

Hilliard, A. (2014). Spoken grammar and its role on the English language classroom. English Teaching Forum, 52(4), 2-13.

Horgues, C. (2013). French learners of L2 English: Intonation boundaries and the marking of lexical stress. Research in Language, 11(1), 41-56.

Howarth, P. (1998). Phraseology and second language proficiency. Applied Linguistics, 19(1), 24-44.

Hulstijn, J. H. (2001). Intentional and incidental second-language vocabulary learning: A reappraisal of elaboration, rehearsal and automaticity. In P. Robinson (Ed.), Cognition and second language instruction (pp. 258-286). Cambridge: Cambridge University Press.

Hulstijn, J. H. (2002). Towards a unified account of the representation, processing and acquisition of second language knowledge. Second Language Research, 18(3), 193-223.

Hulstijn, J. H. (2011). Language proficiency in native and nonnative speakers: An agenda for research and suggestions for second-language assessment. Language Assessment Quarterly, 8(3), 229-249.

Kim, M.-S. (1994). Cross-cultural comparisons of the perceived importance of conversational constraints. Human Communication Research, 21(1), 128-151.

Koponen, M., \& Riggenbach, H. (2000). Overview: Varying perspectives on fluency. In H. Riggenbach (Ed.), Perspectives on fluency (pp. 5-24). Ann Arbor: University of Michigan Press.

Lambert, C., Kormos, J., \& Minn, D. (2017). Task repetition and second language speech processing. Studies in Second Language Acquisition, 39(1), 167-196.

Lantolf, J. P. (2000). Sociocultural theory and second language learning. Oxford: Oxford University Press.

Lantolf, J. P. (2007). Sociocultural theory: A unified approach to L2 learning and teaching. In J. Cummins \& C. Davison (Eds.), International handbook of English Language Teaching (pp. 693-700). Boston, MA: Springer US.

Lantolf, J. P., \& Thorne, S. L. (2006). Sociocultural theory and the genesis of second language development. Oxford: Oxford University Press.

Lennon, P. (1990). Investigating fluency in EFL: A quantitative approach. Language Learning, 40(3), 387-417.

Long, M. H., \& Doughty, C .J. (2003). SLA and cognitive science. In C. Doughty \& M. H. Long (Eds.), The handbook of second language acqcuisition (pp. 866-870). Malden, MA: Blackwell Publishing.

Machado de Almeida Mattos, A. (2000). A Vygotskian approach to evaluation in foreign language learning contexts. ELT Journal, 54(4), 335-345.

McCarthy, M., \& Carter, R. 1995. Spoken grammar: What is it and how can we teach it? ELT Journal 49(3), 207-218.

Nation, P. (1989). Improving speaking fluency. System, 17(3), 377-384.

Nattinger, J. R., \& DeCarrico, J. S. (1992). Lexical phrases and language teaching. Oxford: Oxford University Press.

Niu, R., Lu, K., \& You, X. (2018). Oral language learning in a foreign language context: Constrained or constructed? A sociocultural perspective. System, 74, 38-49.

Ohta, A. (1995). Applying sociocultural theory to an analysis of learner discourse: learnerlearner collaborative interaction in the zone of proximal development. Issues in Applied Linguistics, 6(2), 93-121.

Paradis, M. (2004). A neurolinguistic theory of bilingualism. Amsterdam: Benjamins. 
Paradis, M. (2009). Declarative and procedural determinants of second language learning. Amsterdam: Benjamins.

Pawley, A., \& Syder, F. (1983). Two puzzles for linguistic theory: Native-like selection and native-like fluency. In J. C. Richards \& R. W. Schmidt (Eds.), Language and communication (pp. 191-225). London, UK: Longman.

Raman, Y. (2017). Implementations versus reality: EFL teachers' beliefs about teaching speaking skills in state secondary schools. International Journal of Economic Perspectives, 11(1), 773-781.

Rossiter, M. J., Derwing, T. M., Manimtim, L. G., \& Thomson, R. I. (2010). Oral fluency: The neglected component in the communicative language classroom. The Canadian Modern Language Review, 66(4), 583-606.

Santiago Sanchez, H., \& Borg, S. (2014). Insights into L2 teachers' pedagogical content knowledge: A cognitive perspective on their grammar explanations. System, 44, 45-53.

Schinke-Llano, L. (1993). On the value of a Vygotskian framework for SLA theory and research. Language Learning, 43(1), 121-129.

Searle, J. R. (1969). Speech acts. Cambridge: Cambridge University Press.

Segalowitz, N. (2010). Cognitive bases of second language fluency. New York \& London: Routledge.

Segalowitz, N. (2016). Second language fluency and its underlying cognitive and social determinants. International Review of Applied Linguistics in Language Teaching, 54(2), 79-95.

Sfard, A. (1998). On two metaphors for learning and the dangers of choosing just one. Educational Researcher, 27(2), 4-13.

Schmidt, R. (1992). Psychological mechanisms underlying second language fluency. Studies in Second Language Acquisition 14(4), 357-385.

Shulman, L. S. (1986). Those who understand: Knowledge growth in teaching. Educational Researcher, 15(2), 4-14.

Shulman, L. S. (1987). Knowledge and teaching: Foundations of the New Reform. Harvard Educational Review, 57(1), 1-22.

Skehan, P. (1998). A cognitive approach to language learning. Oxford: Oxford University Press.

Taguchi, N. (2011). Do proficiency and study-abroad experience affect speech act production? Analysis of appropriateness, accuracy, and fluency. International Review of Applied Linguistics in Language Teaching, 49(4), 265-293.

Timmis, I. (2005). Towards a framework for teaching spoken grammar. ELT Journal, 59(2), 117-125.

Towell, R., Hawkins, R., \& Bazergui, N. (1996). The development of fluency in advanced learners of French. Applied Linguistics 17(1), 84-119.

Wajnryb, R. (1990). Grammar dictation. Oxford: Oxford University Press.

Van Compernolle, R., \& Williams, L. (2012). Promoting sociolinguistic competence in the classroom zone of proximal development. Language Teaching Research, 16(1), 39- 60.

Van Driel, J. H., \& Berry, A. (2012). Teacher professional development focusing on pedagogical content knowledge. Educational Researcher, 41(1), 26-28.

Wood, D. (2001). In search of fluency: What is it and how can we teach it? Canadian Modern Language Review, 57(4), 573-589.

Wray, A. (2002). Formulaic language and the lexicon. Cambridge: Cambridge University Press.

Zuengler, J., \& Miller, E. R. (2006). Cognitive and sociocultural perspectives: Two parallel SLA worlds? TESOL Quarterly, 40(1), 35-58. 